\title{
Revisiting studies of
} multicultural school events from the perspective of strategic essentialism

\author{
Joke Dewilde ${ }^{\star 1}$ and Thor-André Skrefsrud ${ }^{2}$ \\ ${ }^{1}$ University of Oslo, Norway; ${ }^{2}$ Inland Norway University of Applied Sciences, Norway
}

\begin{abstract}
The article discusses schools' use of multicultural school events as a practice designed to enhance inclusion and to prevent prejudice and negative intergroup attitudes in school. While prior research has largely criticized such events for promoting cultural stereotypes and essentialist cultural identities, in this article we discuss a more nuanced way of perceiving such practices. Based on our previous empirical work, we apply the idea of strategic essentialism (Spivak, 1996) and discuss how multicultural school events may also represent an opportunity for minority parents to achieve certain objectives by temporarily adopting the image provided by the majority and using it in a strategic manner to act and pursue chosen political advantages. However, we also critically discuss possible limitations and pitfalls of the idea of strategic essentialism as the concept may in fact essentialize the minority group contrary to the intention of the multicultural school event. The contribution of the article is a theoretically informed discussion of how these events may ascribe agency to the participating families, reducing the way critics perceive them solely as victims of a majority-dominated and non-inclusive practice.
\end{abstract}

Keywords: strategic essentialism; cultural stereotypes; inclusion; multicultural events; minority parents

Recieved: January, 2020; Accepted: October, 2020; Published: June, 2021

\section{Introduction}

In this article, we present a theoretical discussion of multicultural school events defined as a practice designed to enhance inclusion and to prevent prejudice and negative intergroup attitudes in school. Applying the idea of strategic essentialism (Spivak, 1996), the article provides a nuanced understanding to prior research, which has largely criticized such events for promoting cultural stereotypes and essentialist 
cultural identities. From a strategic essentialism perspective, multicultural school events represent an opportunity for minority parents to achieve certain objectives by ascribing agency to the participating families and preventing others from perceiving them as victims of a majority-dominated and non-inclusive practice. Through a temporary, strategic approach, the minority engages in a pragmatic standardization of self-representation that apparently accepts the premises set by the majority (Eide, 2010). Based on our previous empirical work on International Day (Dewilde, Kjørven, Skaret, \& Skrefsrud, 2017; Dewilde, Kjørven, \& Skrefsrud, 2021), we discuss the potential of participation in multicultural school events to provide minorities with agency to influence mainstream society; in addition, we draw attention to the possible pitfalls and limitations of strategic essentialism. The purpose of the article is to establish a theoretical understanding of both the potentially positive contributions and the criticism of such events. In this way, we want to contribute to greater insight into how multicultural events in the school might work to build inclusion, what problematic issues such events raise and what opportunities for further development lie in this common but little explored practice.

The article is structured as follows: In the first part, we present and elaborate on the previous critical research on multicultural events in school, using the perspectives of multiculturalism (Kymlicka, 2003) and critical multiculturalism (May \& Sleeter, 2010) as a theoretical lens of understanding. In the second part, we introduce the idea of strategic essentialism (Spivak, 1996) and discuss the potential in understanding multicultural school events from such a perspective. We conclude the article by highlighting some key themes and issues for further research in this area.

\section{Background}

In many countries, parents, students and teachers meet to mark International Day, a multicultural school event, including both single-day and week-long practices (Hovnanian School, n.d.; Municipality of Bærum, n.d.; Troyna, 2012). Such events often take place around 24 October, which is the International United Nation (UN) Day. Many schools set aside the teaching schedule during this time and organize student activities across grades. Some schools use International Day to draw attention to international solidarity and to highlight the UN's achievements in realizing peace, recognizing development and protecting human rights. Other schools work with migrant-related issues and highlight the school's multicultural diversity. In the latter case, the event is often characterized by the need to make visible the countries and cultures represented at the school among the parents and students, in addition to showcasing the products that the students have created during the week. In a previous study, we observed an elementary school in eastern Norway celebrating diversity through a number of activities during International Day. Diverse offerings ranged from courses in Zumba dancing to workshops where the teachers were telling Somali and Russian fairy tales. The students made traditional Sami handicraft, and 


\section{Dewilde E T.-A. Skrefsrud}

they wrote their own travelogues based on the wordless graphic novel The Arrival by Shaun Tan. Several parents participated actively by giving lectures and showing pictures from countries like Romania and Burma. As with many other schools, the week ended with a joint afternoon festival run by the school's parent committee in collaboration with some of the teachers. Parents brought food from their home country, student work appeared in exhibitions and posters showcased different countries. The school also displayed traditional folk costumes and cultural objects from countries to which the students and parents were connected.

This pedagogical practice can be interpreted as a story of resistance. Year after year, schools repeat this event with the aim of reducing and preventing prejudice and xenophobia by highlighting cultural differences and promoting inclusion. By creating a multicultural meeting place to foster greater understanding and community, schools take a proactive stance on the dominant nationalist-populist discourse on diversity, immigration and exclusionary protectionism that characterizes political flows in many European countries, including Norway. International migration within and into Europe has not necessarily helped to build a progressive, cosmopolitan consensus. Instead, populist nationalism has spread the message of protecting national culture and identity from immigration, especially from Muslim countries (Backes \& Moreau, 2012). According to Muis and Immerzeel (2017), right-wing populist nationalism is characterized by "their exclusionist, ethno-nationalist notion of citizenship, reflected in the slogan 'own people first"' (p. 909). Immigration and ethnic diversity are seen as a threat to the nation-state, challenging the sense of identity, meaning and unity. Individuals with national, ethnic, linguistic or religious identities that differ from those of the majority population are defined as the foreign "them" in contrast to the national "we". Social understanding is thus rooted in the fear of a lost idealized past, combined with anxiety over rapid demographic changes and what effect this has on the nation's welfare, jobs and way of life.

Conversely, the educational practice of International Days intends to highlight diversity as a positive resource. Instead of viewing cultural, linguistic and religious differences as problems that should be adapted to the majority or kept outside the purely national borders, schools show that diversity has come to stay. As parents meet, converse and become familiar across linguistic and cultural backgrounds, they share and exchange cultural experiences. In this way, the educational practice of multicultural school events highlights opportunities in a complex community and a multicultural school.

However, multicultural school events may be problematic when reduced to a oneoff event, without integrating the multicultural perspective into everyday activities. As many have noted, such events may counteract their intention (Bartolo \& Smyth, 2009; Hoffman, 1996; Watkins \& Noble, 2019; Øzerk, 2008). When International Day becomes a rare happening, it shows that diversity is not part of the daily activity and may help strengthen cultural divides. Hoffmann (1996) referred to such events in an American school context as "hallway multiculturalism" (p. 546) in which the 
multicultural is on display without being taken seriously. Thus, real inclusive communities cannot be created the way schools intend to. Instead, they paradoxically help reinforce cultural stereotypes and overlook power relations and hierarchies.

Even so, it is conceivable that such events establish meeting places that highlight the cultural and linguistic diversity of the school. The event can help confirm identities, create a common "we" and prevent prejudice and stereotypical beliefs (see Niemi \& Hotulainen, 2016). We find that those attending International Day view the event as an opportunity to both strengthen their group identity and stimulate critical reflection on what such a cultural identity might be (Dewilde et al., 2017; Dewilde et al., 2021). This finding is particularly interesting in light of the research on home-school collaboration, which presents often reported challenges when it comes to engaging parents with minority backgrounds in parenting meetings and other home-school collaboration forums (Bouakaz, 2007; Holm, 2011). International Days may thus create an arena where the experiences of the diverse parent group are being seen and heard while building trust in the school.

\section{Multicultural school events - the critique}

Multicultural school events are designed as a response to the call for diverse and inclusive initiatives to facilitate better understanding, belonging and cohesion in schools (Andersen, 2013; Dewilde et al., 2017). For the participants, International Days are seen as a means for reducing prejudice in school and cultivating a greater tolerance towards cultural, linguistic and religious differences. However, while the schools see these events as helping further inclusion, prior research on the subject has largely criticized such events for promoting essentialist understandings of cultural identities and hence functioning counterproductively with regard to the proclaimed aim of inclusion.

In a Norwegian context, Skoug (1989) conducted the first study on the topic and argued that multicultural events are counterproductive efforts of integration, mainly because they stand out as "special occasions" distinctively separated from the ordinary programme and thus signify Otherness in relation to the "Norwegian norm" (p. 44). Twenty years later, Øzerk had a similar assessment, viewing multicultural educational events as typical practices of "ethnification and festivalization" as well as "appendixation" (Øzerk, 2008, p. 224). "Ethnification" is construed as the binary opposition to "normalization", "festivalization" is opposed to "academication," and "appendixation" is opposed to the practice of presenting cultural expressions not at "the end" but as a natural part of the "ordinary program" (Øzerk, 2008, p. 224). Øzerk therefore claimed that "special events" as a pedagogical practice function counterproductively with regard to the schools' proclaimed aims of community building and inclusion.

In international research, Hoffman $(1996,2015)$ raised a similar critique. In a study of multicultural education in American schools, she introduced the notion of 


\section{Dewilde E T.-A. Skrefsrud}

"hallway multiculturalism," which problematizes the practice of displaying posters and decorations often made up by collages of "ethnic faces" and statements proclaiming "All Cultures are One" and "Diversity for Unity" (Hoffman, 1996, pp. 546-547). In Hoffman's view, what is being promoted is "ideological conformity", or the idea that we should all "think in exactly the same way", which communicates the perspective that all cultures are both fixed and equal and thus can be easily categorized and compared (Hoffman, 1996, p. 547). This approach undermines the experience of real cultural encounters and "the reality of fuzzy borders and mutual interface and interdependency" of cultures (Hoffman, 1996, p. 550). Hoffman concluded that multicultural events reveal that multiculturalism remains an unsolved challenge in schools and argued that schools need to develop an approach that challenges ideological conformity and essentialist understandings of culture. Hoffman's critique thus corresponds with Troyna's (2012) well-known description of the three S's of multicultural education: saris, samosas and steel bands, that is to say, clothing, food and music. By focusing on the exterior of culture, multicultural school events avoid a more critical engagement with deeper issues and become examples of a superficial way of addressing cultural differences in school.

Watkins and Noble (2019) offered a recent example of such a critique in their study of the persistence of the Multicultural Day in Australian schools. Taking an ethnographic orientation to the field of multicultural education, Watkins and Noble examined how the teachers at one school resisted the intellectual task of doing diversity differently. While such events "require significant amounts of labour" (p. 2), Watkins and Noble found that the organizers frequently lacked adequate intellectual labour in examining the underlying assumptions of the event. Instead of improving community relations and countering underlying racism within the school, which was the intended meaning, Watkins and Noble concluded that the event offered little more than a superficial celebration of ethnic difference, which they framed as "lazy multiculturalism" (p. 1). Such events "are 'lazy', not because they don't require labour they do - but because they mobilise 'lazy' stereotypes about cultural differences [that are] flawed representations of the complexities of people's lives" (Watkins \& Noble, 2019 , p. 3). Hence, according to Watkins and Noble, events such as the Multicultural Day are often a result of "unreflexive forms of multicultural education" (p. 2) that "entail simplistic understandings of culture that reproduce essentialised understandings of difference" (p. 2).

From this perspective, International Days are not trivial and harmless practices. Rather, they can be damaging approaches to multicultural education that can work to sustain, aggravate and intensify problems in the school, regardless of good intentions. In line with Ngo's work (2010) on multicultural education, one could thus sum up the criticism by identifying three major problematic issues of such events' celebration of diversity. First, Ngo (2010) argued that such events may overlook deeper issues around complexity and thus miss the opportunity to engage in critical discussions on the groups' representatives and what hierarchies and inner differentiation exist 
within the different cultural communities. Second, they foster simplistic and homogenizing characterizations of cultures, languages and religions. Third, they foster a problematic understanding of what it means to affirm cultural diversity and give recognition to the cultural, linguistic and religious heritage of students and their families (Ngo, 2010, pp. 475-476). As Ngo (2010) noted, multicultural school events can reinforce cultural and religious tensions already existing between the participants and - paradoxically - foster resistance amongst teachers and students towards multiculturalism (see also Watkins \& Noble, 2019, p. 3).

\section{Multiculturalism}

The critique of multicultural school events clearly defines such school initiatives under the category of multiculturalism, a concept educational theorists have critically questioned. Over the past several decades, multiculturalism has served as an educational approach with the aim to affirm and recognize the voice, knowledge and experiences of historically marginalized groups (Ngo, 2010). In opposition to a mainstream classroom limited to a white, Western, monolingual and middle-class dominance, different groups have strived for recognition through multicultural education. Ethnic groups, gay and lesbian individuals, feminists and members of racialized groups have all claimed their rights and questioned how differences should be taught and represented as well as whose perspectives should be integrated in the curricula and in the educational cannon (Banks, 1988). An underlying premise for multiculturalism is the acknowledgment that different cultural communities exist within the same society and that equivalent cultures should be entitled to the same rights (Kymlicka, 2003).

Multiculturalism can be understood in both normative and descriptive ways (Kymlicka, 2003, p. 156). Descriptively, the concept portrays the society or school as a patchwork of different cultural groups living and existing side-by-side. Used in a normative way, multiculturalism includes a political argument for the different groups' rights. Rather than prioritizing some groups at the expense of others, the state should secure equal rights for different cultural communities, such as ethnic minorities, indigenous people, national minorities, linguistic minorities and sexual minorities. By acknowledging the existence of many cultural communities and their entitlement to rights, multiculturalism argues for diversity within the framework of a national identity (Ngo, 2010, p. 475). As such, multiculturalism is a political philosophy that promotes equality and equity between cultural communities to enhance social cohesion and prevent balkanization and hostile conflicts within the plural state.

In schools, the policy of affirming and recognizing differences is most commonly known as "multicultural education", which emerged during the civil rights movement of the 1960s and grew stronger throughout the following decades (Banks, 1988; Gay, 2002; Ladson-Billings, 1995). According to Ngo (2010), the primary goals of multicultural education "include transforming educational institutions so that 


\section{Dewilde E T.-A. Skrefsrud}

students from different racial, ethnic, gender and class backgrounds may have the opportunity for educational equity and success" (p. 475; italics in original). Multicultural education is a critical alternative to an assimilation approach to education that gradually adapts the minority culture to the mainstream. It refuses to renounce the cultural identity and heritage of marginalized groups and argues that a variety of perspectives and histories should be included in the curriculum. By challenging the dominant paradigms and concepts taught in schools, multicultural education seeks to transform a prevailing majority-oriented perspective and ensure the recognition of equal rights for all students.

However, applying a multicultural approach to truly bring about equitable change in the educational system has often proved difficult. While multiculturalism has provided a pioneering and valuable framework for recognizing cultures and cultural differences in school and society, critics have also emphasized the limitations of a multicultural approach by its focus on surface-level inclusion and superficial aspects of culture (May \& Sleeter, 2010). Despite the best of intentions, multicultural education has often been reduced to an uncritical, cosmetic appreciation and celebration of cultural differences, highlighted through isolated events such as International Days (Ngo, 2010, p. 476). From the perspective of critical multiculturalism - to which we now turn - a multicultural education approach runs the risk of maintaining the supremacy of the dominant majority group.

\section{Critical multiculturalism}

Critical multiculturalism draws its inspiration from a range of theories, especially the ideas of the Frankfurt School of social research. In line with the work of Horkheimer, Adorno, Habermas and Honneth, critical multiculturalism seeks to critically analyse the conditions necessary to realize social emancipation, not only for dominant groups, but for all individuals despite race, class, gender, cultural background or ethnicity.

According to May and Sleeter (2010), it is important to ask why structural inequalities continue to persist given that schools have adopted a multicultural approach. For May and Sleeter (2010), this means to highlight the weaknesses of a multicultural approach to education, which is characterized by "its inability to tackle seriously and systematically these structural inequalities, such as racism, institutionalized poverty, and discrimination" (p. 3). This inability is a result of its "continued use of the affirmational and politically muted discourses of 'culture' and cultural recognition" (p. 3), where culture is seen as a characteristic of the individual and a set of practices that can be described, labelled and taught. Although multiculturalism grew from the civil rights movement and has highlighted issues of racism in education, multicultural education has proven insufficient when it comes to recognizing, questioning and altering structural systems of injustice and embedded power. By contrast, critical multiculturalism seeks to highlight structural inequalities that prevent education 
from responding to the variety of needs in a diverse student population and to realize optimal learning conditions for all students (May \& Sleeter, 2010, p. 10).

Critical multiculturalism is concerned with the cultural essentialism and the de-politicization that follows from a multicultural education approach. When culture is treated as something that should be affirmed and recognized, cultural practices and experiences are easily understood as fixed and equal and as something that could be categorized and compared (Hoffman, 1996, 2015). This understanding underlines the conception of cultural identities as integral, unified and related to a specific geographic or ethnic community. Moreover, it undermines the experiences that cultural identities are increasingly being deconstructed, altered and redefined in dynamic processes of change. Paradoxically, multiculturalism is built on the problematic assumption that cultures can be described and understood according to an essence that characterizes each cultural community. Conceptualizing culture in this way, the primary approach is to make the stranger more familiar by acquiring knowledge about distant customs and world-views.

From the perspective of critical multiculturalism, multicultural education reinforces a well-established opinion that we often hear from the media, politicians and even educators: that people from cultural and linguistic minorities are deprived and inferior, both socially and linguistically, and in need of repair (Gitz-Johansen, 2009; Skrefsrud, 2018). The celebration and appreciation of cultures is seen as "the answer to 'the problem' of ethnic and cultural diversity" (May \& Sleeter, 2010, p. 4). While such an answer is easy to implement in schools, it only touches the surface of what acknowledging a diverse student population implies. The problematic essentialist view on culture fails to address unequal power distributions between groups and overlooks the inner differentiation of cultural communities. From this perspective, multicultural school events turn a blind eye to potential hierarchies, tensions and negotiations of identity and representations that take place in school, especially during a multicultural school event. Thus, there is a need to challenge a multicultural education approach and rather stimulate reflexivity, critical thinking and self-awareness to create "opportunities for the kind of learning that leads to transformative understanding" (Hoffman, 1996, p. 550).

\section{Strategic essentialism}

In this last part we return to the role multicultural school events play for the participants, in particular for creating an arena for establishing trustful relationships between the school and the parents. Instead of simply dismissing such events as highly problematic assimilation practices, we introduce the concept of strategic essentialism (Spivak, 1996) and discuss if and how the practice of multicultural school events could be perceived differently from this perspective.

An essentialist view on culture, language and religion claims that a group or a community share some distinctive characteristics which are defined in external contrast 


\section{Dewilde E T.-A. Skrefsrud}

to other groups or communities (Eide, 2010, p. 66). Cultural, linguistic and religious practices are seen as something stable, delimited and coherent that can be observed and described according to their essence.

Historically, the tendency to define cultures according to a specific inner essence can be traced back to Johann Gottfried von Herder (1744-1803). Faced with the historical situation of an expanding and dominating French state, Herder urged the German people to develop a national culture upon a native foundation. The Germans, like any other people, had their own Volkgeist, literally meaning spirit of the people that defined and united the German people as a cultural nation (Schmidt, 1956). The fight for the Germans' right not to be French was thus a driving force for the development of the political ideology of $18^{\text {th }}$ century cultural nationalism. Moreover, cultural nationalism is closely linked with the historical development of scientific disciplines such as anthropology, sociology and cultural studies, which became important tools for providing knowledge about the foreign dark-skinned Other to the white, colonial world. Researchers went to foreign societies to describe and uncover cultural patterns, life-stances and practices of communities and groups, bringing back ethnographic studies that produced "objective" and "true" representations of the exotic Other (Skrefsrud et al., 2018). Hence, describing a culture "on its own terms", which has been the ideal for relativistic, cultural-centred anthropology and sociology, assumes that cultural communities can be studied as coherent, delimited systems.

On these grounds, an essentialist understanding is characterized by three main features that partially overlap. The first feature is the idea that languages, practices and mindsets within a particular community can be traced back to one particular culture of that community (i.e. social homogenization). The second feature is ethnic consolidation, which means that culture always expresses a people's particular cultural practices. Finally, essentialism presupposes segregation in the sense that some people are defined as insiders and others as outsiders. Inner homogenization and ethnic consolidation are combined with outer separation (Welsch, 1999, p. 194).

Essentialism therefore often involves power. It is always someone that attributes certain cultural practices, patterns of behaviours and values and norms to members of a defined group. By selecting and defining the cultural markers that characterize the cultural community, some people set the premises, while others are labelled passively. Said (2003) framed this as "the Oriental discourse" (p. 3), which refers to the West's understanding of the Orient. According to Said, Orientalism presupposes a cultural, social and geographical divide between the East and the West - the Orient and the Occident. The Western image of the Oriental is developed "by making statements about the Orient, authorizing views of it, describing it, by teaching it, settling it, ruling over it" (Said, 2003, p. 3). The West exercises its power by defining the "essence" of the Orient while constructing its own self-image. The Westerner is everything the Oriental is not. Another historical example is the Norwegian nation-building process from the 1850s, in which the authorities gave school a key role in promoting and 
implementing a national culture constructed from a selected set of motives (Engen, 2003). The construction of the Norwegian nation became an early example of what Benedict Anderson (1991) has described as an imagined community.

In contemporary Norway, many young people from cultural and linguistic minorities are experiencing what Eide (2010, p. 67) has framed as a "collective responsibility". Being placed and labelled within a restricted understanding of their home-culture and how it relates to the mainstream, they challenge the power structure of essentialism by refusing to be essentialized. Some years ago, Dewilde (Dewilde \& Skrefsrud, 2016) conducted a study following a young woman named Bahar taking part in local and global communities on Facebook. Bahar subscribed to communities on Facebook which presented alternative stories about Afghanistan other than through a lens fractured by war. One community was "Afghanistan's Next Top Models", which paralleled reality television shows in many countries. Another was "Afghan Culture", which aimed to represent daily life and cultures of Afghans, showing sides of the country that media seldom cover. For Bahar, it was obviously important to present and identify with her home country as a place of beauty with magnificent landscapes, golden sunlight and a brighter future for women. In this sense, Bahar confronted an essentialist description of being Afghan and positioned herself in relation to a more nuanced and multifaceted picture of cultural identity.

We observed a similar example during the multicultural festival at an International Day where a group of students was responsible for making posters with facts and pictures from different countries to be displayed in stalls (Dewilde et al., 2021). The Kurdish representatives named Ara and Nazdar were not happy about the choices made. Ara pointed out that Kurdistan is not situated in northern Iraq, as stated in the poster, and Nazdar would have wanted a picture of a famous waterfall rather than an almost arbitrary mountain range. Unaware that students had made posters before he arrived, Ara had brought information sheets related to different aspects of Kurdistan and Kurdish culture, bilingual children's books and cultural artefacts. These items presented an alternative story of Kurdistan and of what he perceived as important when portraying Kurdish identity.

While the minority may resist essentialization by re-telling stories of a more complex and rich reality as illustrated above, the minority can also resist cultural homogenization in other ways. Spivak's (1996) concept of strategic essentialism has been highly influential in postcolonial thinking, as well as in feminist and queer theory. Spivak (1996) drew attention to the minorities' "strategic use of positivist essentialism in a scrupulously visible political interest" (p. 214). The context for Spivak's work is the attempt to rewrite the history of India from the perspective of the sub-altern, deconstructing the imperial version of the history (see also Eide, 2010). Within this frame of reference, she developed a concept that describes the strategic actions of the oppressed and marginalized, taking on the roles of powerful agents actively working to influence the prevalent current society. For Spivak, essentializing the Other is a positivistic project, which assumes that the very core of a person's cultural life-world 


\section{Dewilde E T.-A. Skrefsrud}

can be revealed and fully understood. However, claiming a positive subject-position, the minority may temporarily adopt the image provided by the majority and use it in a strategic manner to act and pursue chosen political advantages. Strategic essentialism could thus be perceived as a minority strategy for influencing, shaping and changing mainstream society.

In this sense, the concept implies that the minority, while being highly differentiated internally, may actively take up and adapt to the image constructed by the majority. According to Eide (2010), the minority engages "in an essentializing and to some extent a standardization of their public image" (p. 76), which means that the minority provisionally advances "their group identity in a simplified, collectivized way" (Eide, 2010, p. 76). Interpreted in this manner, Spivak's concept is similar to Bhabha's (1994) description of active resistance. Bhabha (1994) illustrated the minority's struggle for recognition by using the concepts of "mimicry" and "mockery" (p. 85), implying that the minority pokes fun at the majority (mockery) by apparently adopting the majority's cultural formations (mimicry). The concept also corresponds with what Pratt (1991) framed as "autoethnographical texts", which often constitute a marginalized group's interaction with the dominant culture in which "people undertake to describe themselves in ways that engage with representations others have made of them" (Pratt, 1991, p. 35).

As noted, the Kurdish parents in our study actively engaged in the school's multicultural festival by bringing typical Kurdish food and cultural representations. In addition, they enthusiastically participated in the catwalk showing their traditional folk clothing while dancing to Kurdish music (Dewilde et al., 2021). Not only did they strategically select these elements, but they also documented their participation by taking pictures and filming. Our bilingual Kurdish research assistant explained that these pictures and video recordings were massively shared through social media with Kurds across the world. We have therefore argued that the Kurds used the event as an opportunity for inward identity construction, consolidating Kurds as an ethnic people with its own culture and traditions, in contrast to their historic and current situation as a people living across four nation-states and many in diaspora.

It could also be argued, however, that this inward identity construction may contribute to mask the diversity, hierarchies and inner differentiation that exist within the cultural group. As clearly stated by Spivak (1996), the idea of strategic essentialism is a strategy, not a theory - and, as a strategy, it suits a situation. A groups' claim for essentialism therefore has to be interpreted in light of the specific situation, namely the context is and how it requires that the minority speak in one voice. When using strategic essentialism as a theory, one risk is that "disempowered groups may ossify into a fixed identity, which can ultimately perpetuate the subordination of the groups they claimed to emancipate" (Morton, 2007, p. 127). As Eide (2010) also has emphasized, "the problem occurs when the practice of strategic essentialism is not the result of a deliberate choice and an assessment of a delicate balance, but rather $[\ldots]$ requires people and groups to essentialize themselves" (p. 76). As such, the idea 
of strategic essentialism always has to be explored critically. On one side, the idea may help to explain how minorities interact with the majority in order to influence mainstream society. On the other side, it always runs the risk of essentializing groups or communities, contrary to its intention.

In sum, although essentialism is highly problematic when it comes to how "the Other" is constructed and understood, Spivak (1996) argued that there is sometimes a political and a social need for strategic essentialism as minority groups represent themselves. This temporary essentialism may create solidarity, despite differences, and a sense of belonging to a particular group in order to act. That being said, interpreting multicultural school events in the light of strategic essentialism does not mean that tendencies to simplistic and homogenizing understandings of cultures and communities are not present in such events. As Spivak has emphasized, the idea of strategic essentialism nuances the understanding of how minorities sometimes need to position themselves in relation to the mainstream society. Despite the possible benefits identified by strategic essentialism the minorities' agency to influence mainstream society by participating in multicultural school events may still be restricted by the way the multicultural events are framed.

\section{Concluding remarks}

In this article, we have discussed the practice of International Days from the perspectives of multiculturalism, critical multiculturalism and strategic essentialism. Applying the idea of strategic essentialism, we have suggested an alternative way of understanding such events that may nuance the dominant critique. While prior research has accused multicultural pedagogical initiatives of being counterproductive to the aim of inclusion, the perspective of strategic essentialism indicates that multicultural school events can represent an opportunity for minority parents by ascribing agency to the participating families rather than perceiving them as victims of a majoritydominated and non-inclusive practice.

For schools, the perspective of strategic essentialism may enhance the awareness of power distribution, hierarchies and tensions in these events, despite their harmonious character. Becoming aware of such a perspective may also inspire involved actors to see beyond a unanimous critique that dismisses this kind of pedagogical practice, and rather critically discuss the potential of such events without falling into the trap of essentializing the diverse lives and cultures of people. Understanding multicultural school events through the lens of strategic essentialism could make them into real cultural meeting places rather than static exhibitions of cultures. However, what may be interpreted as the minorities' agency to conduct inward identity constructions for strategic reasons could also turn out to be a problematic essentialization and reduction of identity applied by the majority. Nevertheless, the idea of strategic essentialism helps us to engage critically with such issues in a way that goes beyond a simple rejection of multicultural school events. 


\section{F. Dewilde E T. $-A$. Skrefsrud}

Future research should further examine multicultural school events from the perspectives of the participating actors. Important issues to explore would be how parents and students construct identities at the events as well as how they reflect on the relation between their cultural representations and the events as a pedagogical practice. As the celebration of cultural diversity in school through multicultural school events does not seem to be decreasing, research should examine the conceptions, worldviews and motivations that underlie our consciousness and pedagogical work. As we have shown, the perspective of strategic essentialism can prove to be helpful in this regard.

\section{Author biography}

Joke Dewilde is Associate Professor of Multilingualism at the Department of Teacher Education and School Research at University of Oslo, Norway. Her research interests include multilingualism in education and creative research methodology. She is the co-author of the article "International week in a Norwegian school: A qualitative study of the participant perspective" in Scandinavian Journal of Educational Research (with Kjørven, Skaret and Skrefsrud).

Thor-André Skrefsrud is Professor of Education at the Faculty of Education at Inland Norway University of Applied Sciences, Norway. His research interests include multicultural education and educational philosophy. $\mathrm{He}$ is co-author of the article "Multicultural school festival as a creative space for identity construction - from a minority parent perspective" in Intercultural Education (with Dewilde and Kjørven).

\section{References}

Andersen, F. C. (2013). Leadership in a linguistically and ethnically diverse upper secondary school: Responding to challenges. Nordic Studies in Education, 32, 31-49.

Anderson, B. (1991). Imagined communities: Reflections on the origin and spread of nationalism. Verso.

Dewilde, J., Kjørven, O. K., Skaret, A. \& Skrefsrud, T.-A. (2017). International week in a Norwegian school: A qualitative study of the participant perspective. Scandinavian fournal of Educational Research, 62(3), 474-486. https://doi.org/https://doi.org/10.1080/00313831.2017.1306800

Dewilde, J., Kjørven, O. K. \& Skrefsrud, T.-A. (2021). Multicultural school festival as a creative space for identity construction - from a minority parent perspective. Intercultural Education, 32(1).

Dewilde, J. \& Skrefsrud, T.-A. (2016). Including alternative stories in the mainstream: How transcultural young people in Norway perform creative cultural resistance in and outside of school. International fournal of Inclusive Education, 20(10), 1032-1042. https://doi.org/10.1080/13603116.2016.1145263

Backes, U., \& Moreau, P. (Eds.). (2012). The extreme right in Europe: Current trends and perspectives. Vandenhoeck and Ruprecht.

Banks, J. A. (1988). Multiethnic education: Theory and practice (2nd ed.). Allyn and Bacon.

Bartolo, P., \& Smyth, G. (2009). Teacher education for diversity. In A. Swennen \& M. v. d. Klink (Eds.), Becoming a teacher educator. Theory and practice for teacher educators (pp. 117-132). Springer.

Bhabha, H. K. (1994). The location of culture. Routledge.

Bouakaz, L. (2007). Parental involvement in school: What hinders and what promotes parental involvement in an urban school [Unpublished doctoral dissertation]. Malmö University, Faculty of Social Sciences, Malmö.

Eide, E. (2010). Strategic essentialism and ethnification. Nordicom Review, 31(2), 63-78. 


\section{Revisiting studies of multicultural school events from the perspective of strategic essentialism}

Engen, T. O. (2003). Enhetsskolen og flerkulturell nasjonsbygging [Comprehensive school and multicultural nation-building] In P. Østerud \& J. Johnsen (Eds.), Leve skolen! Enhetskolen $i$ et kulturkritisk perspektiv [Long live the school! Comprehensive school in a culture-critical perspective] (pp. 231-250). Oplandske Bokforlag.

Gay, G. (2002). Preparing for culturally responsive teaching. Fournal of Teacher Education, 52(2), 106-116.

Gitz-Johansen, T. (2009). Muligheder og barrierer i den flerkulturelle skole - om holdninger, modstand, pædgogik og anerkendelse. [Possibilities and barriers in the multicultural school - on attitudes, resistance, pedagogy and recognition] In O. K. Colleague, B.-K. Ringen, \& A. Gagné (Eds.), Teacher diversity in diverse schools Challenges and opportunities for teacher education (pp. 391-410). Oplandske Bokforlag.

Hoffman, D. M. (1996). Culture and self in multicultural education: Reflections on discourse, text, and practice. American Educational Research fournal, 33(3), 545-569.

Hoffman, D. M. (2015). Quiet riot:The culture of teaching and learning in schools. Rowman \& Littlefield Education.

Holm, I. M. (2011). Somaliere og norsk skole: En studie av somaliere $i$ Norge med scerlig fokus på relasjoner mellom lerere og foreldre [Somalies and Norwegian school: A study of Somalies in Norway with a particular focus on the relations between teachers and parents] [Unpublished doctoral dissertation]. University of Tromsø.

Hovnanian School. (n.d.). International day. Retrieved from https://www.hovnanianschools.org/international-day

Kymlicka, W. (2003). Multicultural states and intercultural citizens. Theory and Research in Education, 1(2), 147-169.

Ladson-Billings, G. (1995). Toward a theory of culturally relevant pedagogy. American Educational Research fournal, 32(3), 465-491.

May, S., \& Sleeter, C. E. (Eds.). (2010). Critical multiculturalism: Theory and praxis. Routledge.

Morton, S. (2007). Gayatri Spivak: Ethics, subaltern and the critique of postcolonial reason. Polity Press.

Muis, J., \& Immerzeel, T. (2017). Causes and consequences of the rise of populist radical right parties and movements in Europe. Current Sociology, 65(6), 909-930. https://doi.org/10.1177/0011392117717294

Municipality of Bærum. (n.d.). Internasjonal uke [International week]. Retrieved from https://www. rykkinnskole.no/?artID $=2996$

Ngo, B. (2010). Doing “diversity” at Dynamic High: Problems and possibilities of multicultural education in practice. Education and Urban Society, 42(4), 473-495. https://doi.org/10.1177/0013124509356648

Niemi, P.-M., \& Hotulainen, R. (2016). Enhancing students' sense of belonging through school celebrations: A study in Finnish lower-secondary schools. International fournal of Research Studies in Education, 5(2), 1-16. https://doi.org/10.5861/ijrse.2015.1197

Pratt, M. L. (1991). Arts of the contact zone. Profession, 91, 33-40.

Said, E. W. (2003). Orientalism. Routledge \& Kegan Paul Ltd.

Schmidt, R. J. (1956). Cultural nationalism in Herder. Fournal of the History of Ideas, 17(3), 407-417.

Skoug, T. (1989). To-kulturelt arbeide $i$ barnehagen [Bi-cultural work in kindergarten] Oplandske Bokforlag.

Skrefsrud, T.-A. (2018). Barriers to intercultural dialogue. Studies in Interreligious Dialogue, 28(1), 43-57. https:// doi.org/10.2143/SID.28.1.3285343

Skrefsrud, T.-A., Gísladóttir, K. R., Gudjónsdóttir, H., Hellman, A., Layne, H., Lunneblad, J. \& Wozniczka, A. (2018). Research methodologies for a culturally diverse educational context. I H. Ragnarsdóttir \& L. A. Kulbrandstad (Red.), Learning spaces for inclusion and social justice. Success stories from four Nordic countries (s. 94-118). Cambridge Scholars Publishing.

Spivak, G. C. (1996). Subaltern studies: Deconstructing historiography. In D. Landry \& G. MacLean (Eds.), The Spivak reader. Selected works of Gayatri Chakravorty Spivak (pp. 203-235). Routledge.

Troyna, B. (Ed.). (2012). Racial inequality in education. Taylor \& Francis.

Watkins, M., \& Noble, G. (2019). Lazy multiculturalism: Cultural essentialism and the persistence of the Multicultural Day in Australian schools. Ethnography and Education. https://doi.org/10.1080/17457823.20 19.1581821

Welsch, W. (1999). Transculturality: The puzzling form of cultures today. In M. Featherstone \& S. Lash (Eds.), Spaces of culture. City, nation, world (pp. 194-213). Sage Publications.

Øzerk, K. (2008). Interkulturell danning i en flerkulturell skole: Dens vilkår, forutsetninger og funksjoner [Intercultural Bildung in a multicultural school: Its conditions, requirements and functions]. In P. Arneberg \& L. G. Briseid (Eds.), Fag og danning: Mellom individ og fellesskap [Subject and Bildung: Between individual and community] (pp. 209-228). Fagbokforlaget. 